\title{
AGRO-TECHNICAL DOCUMENTATION AS A SUPPORTING TOOL IN PRESENTING INFORMATION IN FARM FINANCIAL STATEMENTS ${ }^{4}$
}

\begin{abstract}
The purpose of this paper is to propose a method for the presentation of farming operations in farm financial statements with the use of agro-technical documentation kept by the farmers, as illustrated by the example of crop farms. Research methodology: to pursue the objective set out in this paper, the relevant literature and the applicable legal regulations were reviewed. From 2015 to 2017, in-depth personal interviews were conducted with the farms' chief accountants (30 persons) and farm owners (150 persons) who keep their records in accordance with the Accounting Act. The farms were located in the Wielkopolskie Voivodeship. The subject addressed in in-depth interviews was the disclosure of non-financial information in farm financial statements. Result: the presentation of the farms' business performance needs to be much more detailed. The results of research on the scope of non-financial information disclosure in farm financial statements were presented. The agro-technical documentation was reviewed in 30 farms.
\end{abstract}

Keywords: non-financial information, financial statement, farms.

\section{INTRODUCTION}

Farming is of a heterogeneous nature as it involves both production and processing activities. In turn, agricultural production is a continuous process. The arrested plant growth

\footnotetext{
${ }^{1}$ Małgorzata Węgrzyńska, Ph.D. in engineering, Assistant Professor, Faculty of Economics and Social Sciences, Poznań University of Life Sciences, e-mail: malgorzata.wegrzynska@up. poznan.pl (corresponding author).

Dr inż. Małgorzata Węgrzyńska, Wydział Ekonomiczno-Społeczny, Uniwersytet Przyrodniczy w Poznaniu, e-mail: malgorzata.wegrzynska@up.poznan.pl (autor korespondencyjny).

${ }^{2}$ Xesús Pereira López, Professor at the Faculty of Business Administration and Management, University of Santiago de Compostela

Prof. Xesús Pereira López, Wydział Administracji i Zarządzania, Uniwersytet Santiago de Compostela.

${ }^{3}$ Manuel Veiga Carballido, Professor at the Faculty of Business Administration and Management, University of Santiago de Compostela

Prof. Manuel Veiga Carballido, Wydział Administracji i Zarządzania, Uniwersytet Santiago de Compostela.

4 The paper is funded by the National Science Centre within the MINIATURA 1 research project No. NCN DEC-2017/01/X/HS4/01742, entitled "Valuation methods of biological assets in agricultural activity" (Metody wyceny aktywów biologicznych w działalności rolniczej).
} 
during winter dormancy is only an illusion and does not contradict the above; otherwise, it would be impossible to determine the value of that process. Accounting, which means the activity of counting, starts by valuating different events ${ }^{5}$. The diversified nature of agricultural production makes it difficult to present economic events in accounting records, and especially to provide a reliable, trustworthy presentation of financial information and data in financial statements. The Accounting Act ${ }^{6}$ in force fails to fully address the specific nature of farming activities. That activity is reflected in the Draft National Accounting Standard "Farming activity" (http://www.mf.gov.pl) and in International Accounting Standard 41 "Agriculture" . According to the recommendations set out in accounting standards, a farm who keeps accounting records and delivers financial statements must present a management method for the biological transformation of animals and plants (biological assets) for the purposes of sale, agricultural production or creation of additional biological assets ${ }^{8}$. In the case of farming activities, the above is an extremely difficult task which requires a lot of time. Therefore, it may be concluded that a traditionally defined financial statement fails to provide the stakeholders with actionable information which could be used when making decisions affecting the farm's operations. The essential information for the decision-making process may be found primarily in accounting records and in auxiliary agricultural documentation which should be disclosed in the annual financial statement.

The purpose of this paper is to propose a method for the presentation of observable events associated with farming operations in farm financial statements with the use of agro-technical documentation kept by the farmers, as illustrated by the example of crop farms.

\section{RESEARCH METHOD}

To pursue the objective set out in this paper, a review was made of relevant literature and of legal regulations applicable to non-financial information disclosure in farm financial statements. Also, from 2015 to 2017, in-depth personal interviews were conducted with the farms' chief accountants (30 persons) and farm owners (150 persons) who keep their records in accordance with the Accounting Act. The farms were located in the Wielkopolskie Voivodeship. The in-depth interviews enabled the identification of key areas of non-financial information which, though needed, have not been included in financial statements. The agro-technical documentation was reviewed in 30 farms.

\footnotetext{
${ }^{5}$ R. Manteuffel Rachunkowość rolnicza (Agricultural accounting), Vol. 1, Warsaw 1965, s. 9.

${ }^{6}$ Accounting Act of September 29, 1994, Journal of Laws (Dz.U. nr 121, poz. 591 ze zm.).

7 Commission Regulation (EC) No. 1126/2008 of November 3, 2008 adopting certain international accounting standards in accordance with Regulation (EC) No. 1606/2002 of the European Parliament and of the Council.

${ }^{8}$ M. Węgrzyńska, L. Majchrzak, Korzyści biologiczne jako miernik spotecznej odpowiedzialności biznesu gospodarstw rolnych (Biological benefits as a yardstick of corporate social responsibility of agricultural holdings), Scientific Papers of the Wrocław University of Economics, No. 478, 2017, p. 437.
} 


\section{SOURCES OF FINANCIAL AND NON-FINANCIAL INFORMATION RELATED TO AGRICULTURAL ACTIVITY OF FARMS}

Because of the importance of information it contains, a financial statement must provide a reliable image of the financial and asset situation of the economic operator concerned. Therefore, each operator required to deliver a yearly financial statement must do so in accordance with the principles provided for in applicable legal regulations and international guidance. In any industry, the primary purpose of the selection and proper analysis of information is to support the economic activity ${ }^{9}$. In order for the support to be effective, the characteristics of useful information - which fall into the following two groups-must be considered. The first group are general characteristics of useful information which include: exactness, timeliness, completeness and relevance; the second group are characteristics of useful information in a financial statement, including: clarity, actionability, significance, reliability, neutrality, prudence and completeness (Table 1).

In a traditionally defined financial statement, financial information presents the condition of assets and of economic events affecting that condition in pecuniary terms only ${ }^{10}$; this is not the only kind of information required for an adequate management of an agricultural holding ${ }^{11}$. The role of non-financial information in farming activities cannot be overestimated because in order to ensure efficient operations, the farmers must consider their activity from the perspective of living plants and animals, and need to take physiological and biological processes into account. This is the very foundation of the farming business which is decisive for the agricultural holding's performance ${ }^{12}$. Therefore, considering the specific nature of farming activities and the applicable international guidance, it becomes necessary to supplement the financial information contained in financial statements with non-financial information ${ }^{13}$.

In the context of farming activities, the sources of financial and non-financial information were defined based on relevant research and were split into two areas. The first one represents sources of financial information while the second one means sources of non-financial information (Figure 2). The first area is strictly related to the accounting information system composed of the following information processing stages: identification, measurement and appraisal, documentation, recording, inventorying. As the last stage, financial information is aggregated into defined reporting categories (items) ${ }^{14}$.

${ }_{9}$ P. Sajna, J. Wawrzynowicz, K. Wajszczuk, Analiza wykorzystania informacji dla potrzeb wspomagania zarzadzania procesami logistycznymi (Analysis of how information is used to support the management of logistic processes), ,Zarządzanie i Finanse”, 11.1, part 3, s. 340.

${ }^{10}$ M. Kostera M. (eds.), Nowe kierunki w zarzadzaniu (New trends in management), Warsaw 2008, s. 160.

${ }^{11}$ P. Sajna, J. Wawrzynowicz , K. Wajszczuk, Analiza wykorzystania informacji..., s. 341.

12 T. Kondraszuk, Rolniczy kalendarz rachunkowy (RKR) jako narzędzie ewidencji, planowania $i$ kontroli $w$ gospodarstwie wiejskim (Agricultural accounting calendar as a recording, planning and inspection tool for rural holdings), „Ekonomika i Organizacja Gospodarki Żywnościowej” 2008, p. 98.

${ }^{13}$ Directive 2014/95/EU of the European Parliament and of the Council of October 22, 2014 amending Directive 2013/34/EU as regards disclosure of non-financial and diversity information by certain large undertakings and groups.

${ }^{14}$ B. Nita (eds.), Podstawy rachunkowości (Basics of accounting), Publishing House of the Wrocław University of Economics 2017, p. 366 
Table 1. Characteristics of useful information

\begin{tabular}{|c|c|c|}
\hline $\begin{array}{l}\text { Grouped } \\
\text { characte- } \\
\text { ristics }\end{array}$ & Characteristics & Description of characteristics \\
\hline \multirow{4}{*}{ 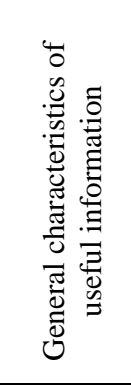 } & Exactness & $\begin{array}{l}\text { Information is exact if it provides a precise and reliable reflection of } \\
\text { realities. }\end{array}$ \\
\hline & Timeliness & $\begin{array}{l}\text { Timely information is available in sufficient time to allow the } \\
\text { company manager to take adequate actions. }\end{array}$ \\
\hline & Completeness & $\begin{array}{l}\text { Information is complete if it provides the company manager with all } \\
\text { required facts and details. }\end{array}$ \\
\hline & Relevance & $\begin{array}{l}\text { Information is relevant if the manager is certain that the information } \\
\text { is useful in his/her company's specific operating conditions and } \\
\text { addresses the company's needs. }\end{array}$ \\
\hline \multirow{7}{*}{ 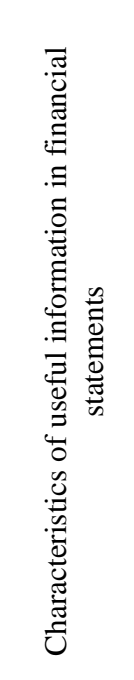 } & Clarity & $\begin{array}{l}\text { Information should be prepared so as to be understandable } \\
\text { (transparent and clear) to users who have sufficient knowledge on } \\
\text { the company's economic activity and on methods employed to } \\
\text { record the company's processes. }\end{array}$ \\
\hline & Actionability & $\begin{array}{l}\text { Information is actionable if the disclosure thereof may have an } \\
\text { impact on the user's decision. }\end{array}$ \\
\hline & Significance & $\begin{array}{l}\text { Information is significant if, rather than being excessively extended, } \\
\text { it focuses on key issues which enable an accurate assessment of past } \\
\text { events and a specification of future actions. }\end{array}$ \\
\hline & Reliability & $\begin{array}{l}\text { Information must be error-free, impartial, objective and complete, } \\
\text { and must reflect the economic operator's actual condition. }\end{array}$ \\
\hline & Neutrality & Information cannot directly affect the decision guidance process. \\
\hline & Prudence & $\begin{array}{l}\text { A characteristic which refers to taking defined precautionary } \\
\text { measures. }\end{array}$ \\
\hline & Completeness & $\begin{array}{l}\text { Any and all information, consequences of economic events and } \\
\text { assets must be presented in compliance with legal regulations. }\end{array}$ \\
\hline
\end{tabular}

Source: own elaboration based on P. Sajna, J. Wawrzynowicz, K. Wajszczuk, Analiza wykorzystania informacji..., s. 341; Accounting Act of September 29; Commission Regulation (EC) No. 1126/2008 of November 3, 2008 adopting certain international accounting standards in accordance with Regulation (EC) No. 1606/2002 of the European Parliament and of the Council).

When disclosing non-financial information, it becomes imperative to use the farm's documentation which includes the description of the following: 1. farming conditions, including: soil, agro-technical and weather conditions; 2. a brief characteristic of crop production, including the share of crops, output and yields, and a description of crop rotation.

The farm's documentation provides a summary of selected farming business conditions presented in the statement. Table 2 includes a summary of farming business conditions, sources of information and a brief description of the documentation. 


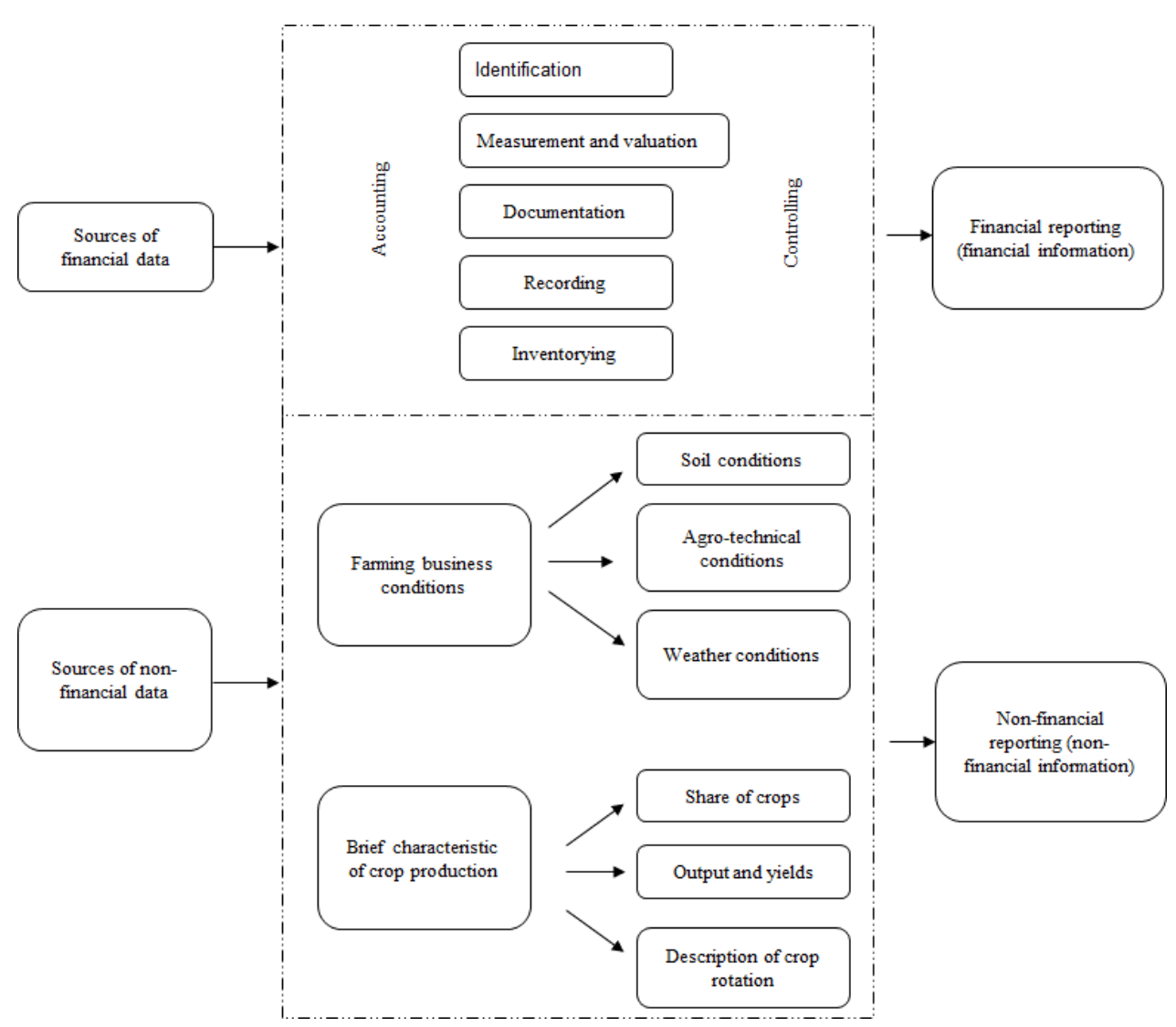

Figure 1. Sources of financial and non-financial information in the context of farming operations

Source: own elaboration based on B. Nita (eds.), Podstawy rachunkowości...; Accounting Act of September 291...; M. Śmiglak-Krajewska, M. Węgrzyńska, Bioróżnorodność w sprawozdaniu finansowym $w$ odniesieniu do uprawy tubinu żóttego (Biodiversity in financial statements regarding yellow lupin cultivation), "Ekonomiczne Problemy Usług" 2017, 2 (127), 309-319.

Meanwhile, according to research, $63 \%$ of farm owners found it important to disclose their soil conditions because soil is the main productive input, and the type and quality of soil is decisive for the production lines. They also emphasized the importance of disclosing the structure of agricultural land and soil quality (soil valuation classes). In turn, chief accountants (13\%) claimed that the farm should be described as a whole, and the average soil quality should be specified for the entire farm.

Both groups (97\% of farm owners and $76 \%$ of chief accountants) emphasized that the farm's location provides information on regional climate conditions which directly translate into crop production inputs and yields. When it comes to land relief, the information disclosed should specify whether arable land is located on a flat, hilly or mountainous area. Another disclosure is the assessment of prevailing climate conditions. As a productive input, climate is equally important as soil. Both groups of respondents find climate to be 
Table 2. Selected farming business conditions

\begin{tabular}{|c|c|c|}
\hline Conditions & $\begin{array}{l}\text { Sources of } \\
\text { information }\end{array}$ & Brief description \\
\hline Soil conditions & $\begin{array}{l}\text { 1. Excerpt from the } \\
\text { soil register } \\
\text { 2. Farm map } \\
\text { 3. Leasing and len- } \\
\text { ding agreements } \\
\text { 4. Farm's soil map } \\
\text { 5. Analysis of the } \\
\text { farm's soil }\end{array}$ & $\begin{array}{l}\text { 1. The farm map specifies the geographic location and } \\
\text { traces the boundaries. Also, it includes information } \\
\text { on soil types and classes, land relief and the location } \\
\text { of roads, streams, forests, trees and buildings. } \\
\text { 2. The soil map is the map of land which specifies the } \\
\text { type, acidity and mineral content of soil. } \\
\text { 3. The layout diagram presents the delimitation and size } \\
\text { of fields. }\end{array}$ \\
\hline $\begin{array}{l}\text { Agro-technical } \\
\text { conditions }\end{array}$ & Field sheet & $\begin{array}{l}\text { Field sheets include information on: } \\
\text { 1. Cultivated species and varieties, } \\
\text { 2. Quantity and type of fertilizers, } \\
\text { 3. Type of crops, quantities harvested and stages of the } \\
\text { growing season. }\end{array}$ \\
\hline $\begin{array}{l}\text { Weather } \\
\text { conditions }\end{array}$ & $\begin{array}{l}\text { Information from } \\
\text { weather stations }\end{array}$ & $\begin{array}{l}\text { Short characteristics of the climate in the area where the } \\
\text { farm is located, including: } \\
\text { annual rainfall, humidity, hours of sunshine, snow } \\
\text { retention time etc. Weather conditions affect the } \\
\text { following, without limitation: } \\
\text { 1. Crop yields, } \\
\text { 2. Crop production quality, } \\
\text { 3. Length of the growing season, } \\
\text { 4. Occurrence of diseases, } \\
\text { 5. Other. }\end{array}$ \\
\hline
\end{tabular}

Source: own elaboration based on T. Michalski, H. Sulewska, H. Waligóra, A. Dubas, Reakcja odmian kukurydzy uprawianej na ziarno na zmienne warunki pogodowe (Response of maize varieties harvested for grain to variable weather conditions), "Annuals of Agricultural Sciences. A Series: Vegetable production" 1996 112(1-2), 103-111; J. Sowiński, A. Liszka-Podkowa, Wielkość i jakość plonu świeżej i suchej masy kukurydzy oraz sorga cukrowego (Sorghum bicolor (L.) Moench.) na glebie lekkiej w zależności od dawki azotu (Quantity and quality of yields of fresh maize dry matter and sorghum (Sorghum bicolor (L.) Moench.) cultivated on light soil in function of nitrogen inputs), "Acta Scientiarum Polonorum. Agricultura" 2008, 7(4); H. Waligóra, W. Skrzypczak, A. Weber, P. Szulc, Plonowanie i dtugość okresu wegetacji kilku odmian kukurydzy cukrowej w zależności od warunków pogodowych (Yields and length of the growing season of several sweet corn varieties in function of weather conditions), "Nauka. Przyroda. Technologie"2010, 4(1), 5; K. Panasiewicz, Wpływ czynników pogodowych i agrotechnicznych na wzrost i plonowanie pszenżyta jarego (Impact of weather and agro-technical factors on the growth and yield of spring triticale), Publishing House of the Poznań University of Life Sciences, 2013.

a highly important factor which cannot be ignored as a piece of non-financial information in the integrated financial statement. Both groups emphasized that by consistently describing the agro-technical conditions they may deliver a variety of information, including the farm's environmental impact and contribution to social capital. As a consequence, the recipient of the financial statement is able to determine the impact of the intensity of agro-technical efforts on crop yields (both in quantitative and qualitative terms), and the condition of arable land. Also, based on this information, one may specify the degree 
of arable land degradation and the quality of food produced. When it comes to crop production characteristics, the following should be disclosed: share of crops, output, yields and description of crop rotation (76\% of farm owners and $64 \%$ of chief accountants). All of the above information may be retrieved from the field sheet. The share of crops means a percentage share of each plant group or species grown in the total area of arable land owned by the farm. For a specific farm, the share of crops is specified for each crop rotation, i.e. the system of arable land management based on a predefined multiannual rotation of crops within a dedicated area which is split into fields and adjusted to the farm's specific agro-economic conditions ${ }^{1516}$. The main objective of crop rotation is to improve soil fertility which translates into higher quantity and better quality of the farm's crop output (and, indirectly, of animal output). From the economic point of view, this means building the value of assets. Also, crop rotation is highly important in the prevention of serious phytopathological diseases (and is often the key prevention method). It also plays a major role as a weed eradication practice ${ }^{1718}$.

According to the interviewees' opinions on the required scope of farm information, it should be considered whether to include the aspects listed above as a fixed supplementary report to the farm financial statement.

\section{SUMMARY AND CONCLUSIONS}

The preparation of a financial statement together with the disclosure of the farm's nonfinancial information poses a problem to the existing accounting system. Adequate source information is needed to assess the activity and financial standing of an agricultural holding. The quality of this data affects the adequacy of the analysis of an economic operator's business and the accuracy of micro- and macroeconomic decisions. Therefore, the following conclusions may be drawn from this survey:

1. It is imperative to establish the National Accounting Standard "Farming activity" which would address the demand of financial and accounting authorities having competence over the agricultural sector.

2. It is imperative to rely on the agro-technical documentation when preparing non-financial information in a financial statement.

3. It is imperative to set out the principles for the presentation of non-financial and financial information in farm financial statements.

4. The benefit from presenting non-financial information in a non-financial report is that it shows the farm's value in much broader terms than the currently applicable financial reporting principles.

5. Another benefit is that financial information is combined with non-financial information which provides a clear and reliable picture of the farming business.

6. Financial statements submitted by farms fail to sufficiently comply with the characteristics of usable information.

\footnotetext{
${ }^{15}$ R. Krężel, D. Parylak, L. Zimny, Zagadnienia uprawy roli i roślin (Cultivation of crops and farming practices), Wrocław 1999.

16 B. Świętochowski, B. Jabłoński, R. Krężel, M. Radomska, Ogólna uprawa roli i roślin (General farming practices and plant cultivation), 4th edition (as reviewed), Warszawa 1996.

17 R. Krężel, D. Parylak, L. Zimny, Zagadnienia uprawy roli i roślin...

18 B. Świętochowski, B. Jabłoński, R. Krężel, M. Radomska, Ogólna uprawa roli i roślin...
} 


\section{REFERENCES}

1. Kondraszuk T., Rolniczy kalendarz rachunkowy (RKR) jako narzędzie ewidencji, planowania $i$ kontroli $w$ gospodarstwie wiejskim (Agricultural accounting calendar as a recording, planning and inspection tool for rural holdings), „Ekonomika i Organizacja Gospodarki Żywnościowej” 2008, p. 97-108.

2. Kostera M. (eds.), Nowe kierunki w zarzadzaniu (New trends in management), Wydawnictwa Akademickie i Profesjonalne, Warszawa 2008.

3. Krężel R., Parylak D., Zimny L., Zagadnienia uprawy roli i roślin (Cultivation of crops and farming practices), Wrocław University of Agriculture, Wrosław 1999.

4. Manteuffel R., Rachunkowość rolnicza (Agricultural accounting), Vol. 1, Państwowe Wydawnictwo Rolnicze i Leśne, Warszawa 1965.

5. Michalski T., Sulewska H., Waligóra H., Dubas A., Reakcja odmian kukurydzy uprawianej na ziarno na zmienne warunki pogodowe (Response of maize varieties harvested for grain to variable weather conditions), "Annuals of Agricultural Sciences. A Series: Vegetable production" 1996, 112(1-2), 103-111.

6. Nita B. (eds.), Podstawy rachunkowości (Basics of accounting), Publishing House of the Wrocław University of Economics, Wrocław 2017.

7. Panasiewicz K., Wpływ czynników pogodowych i agrotechnicznych na wzrost i plonowanie pszenzyta jarego (Impact of weather and agro-technical factors on the growth and yield of spring triticale), Publishing House of the Poznań University of Life Sciences, 2013.

8. Sajna P., Wawrzynowicz J., Wajszczuk K., Analiza wykorzystania informacji dla potrzeb wspomagania zarzadzania procesami logistycznymi (Analysis of how information is used to support the management of logistic processes), ,Zarządzanie i Finanse” 2013, 11.1, part 3: 337-347.

9. Śmiglak-Krajewska M., Węgrzyńska M., Bioróżnorodność w sprawozdaniu finansowym $w$ odniesieniu do uprawy tubinu żóltego (Biodiversity in financial statements regarding yellow lupin cultivation), "Ekonomiczne Problemy Usług" 2017, 2 (127), 309-319.

10. Sowiński J., Liszka-Podkowa A., Wielkość i jakość plonu świeżej i suchej masy kukurydzy oraz sorga cukrowego (Sorghum bicolor (L.) Moench.) na glebie lekkiej w zależności od dawki azotu (Quantity and quality of yields of fresh maize dry matter and sorghum (Sorghum bicolor (L.) Moench.) cultivated on light soil in function of nitrogen inputs), "Acta Scientiarum Polonorum. Agricultura" 2008, 7(4).

11. Świętochowski B., Jabłoński B., Krężel R., Radomska M., Ogólna uprawa roli i roślin (General farming practices and plant cultivation), $4^{\text {th }}$ edition (as reviewed), PWRiL, Warsaw 1996.

12. Waligóra H., Skrzypczak W., Weber A., Szulc P., Plonowanie i dtugość okresu wegetacji kilku odmian kukurydzy cukrowej w zależności od warunków pogodowych (Yields and length of the growing season of several sweet corn varieties in function of weather conditions), "Nauka. Przyroda. Technologie" 2010, 4(1), 5.

13. Węgrzyńska M., Majchrzak L., Korzyści biologiczne jako miernik spotecznej odpowiedzialności biznesu gospodarstw rolnych (Biological benefits as a yardstick of corporate social responsibility of agricultural holdings), ,Scientific Papers of the Wrocław University of Economics" 2017, No. 478, p. 436-443. 


\section{LEGAL ACTS}

1. ACCOUNTING ACT OF SEPTEMBER 29, 1994, JOURNAL OF LAWS (DZ.U. NR 121, POZ. 591 ZE ZM.).

2. Commission Regulation (EC) No. 1126/2008 of November 3, 2008 adopting certain international accounting standards in accordance with Regulation (EC) No. 1606/2002 of the European Parliament and of the Council.

3. Directive 2014/95/EU of the European Parliament and of the Council of October 22, 2014 amending Directive 2013/34/EU as regards disclosure of non-financial and diversity information by certain large undertakings and groups.

\section{SOURCES}

1. National Accounting Standard No. 11 "Farming Activity." Draft of September 18, 2017 (as reviewed); http://www.mf.gov.pl/; [accessed on January 9, 2018]

2. http://www.mf.gov.pl.

\section{DOKUMENTACJA AGROTECHNICZNA JAKO NARZECZZIE WSPOMAGAJĄCE PREZENTACJE INFORMACJI W SPRAWOZDANIU FINANSOWYM Z DZIAŁALNOŚCI GOSPODARSTWA ROLNEGO}

Celem artykułu jest propozycja prezentacji działalności rolniczej w sprawozdaniu finansowym gospodarstwa rolnego na przykładzie produkcji roślinnej z uwzględnieniem prowadzonej przez rolnika dokumentacji agrotechnicznej.

Metodologia badania: aby zrealizować cel artykułu przeprowadzono przegląd literatury przedmiotu i obowiązujących regulacji prawnych. W okresie od 2015 r. do 2017 r. przeprowadzono indywidualne wywiady pogłębione $\mathrm{z}$ głównymi księgowymi gospodarstw rolnych (30 osób) oraz właścicielami gospodarstw rolnych (150 osób) prowadzących ewidencję zgodnie z ustawą o rachunkowości zlokalizowanych na terenie województwa wielkopolskiego. Wywiad pogłębiony przeprowadzono na temat raportowania informacji niefinansowych w sprawozdaniu finansowym gospodarstw rolnych.

Wynik: prezentacja wyników działalności rolniczej wymaga szczegółowego doprecyzowania. Przedstawiono wyniki badań związanych z zakresem ujawnień informacji niefinansowej w sprawozdaniu finansowym gospodarstwa rolnego. Przeprowadzono przegląd dokumentacji agrotechnicznej w 30 gospodarstwach.

Słowa kluczowe: informacje niefinansowe, sprawozdanie finansowe, gospodarstwa rolne.

DOI: $10.7862 /$ rz.2018.hss.91

Tekst złożono do redakcji: czerwiec 2018 r.

Tekst przyjęto do druku: grudzień 2018 r. 
